\title{
Australia's Strategic Environment: The Problem of Papua
}

\author{
Richard Chauvel
}

A proposal from Indonesia's House of Representatives to the government, in January 2004, that an integrated operation be conducted in Papua and a state of civil emergency declared, suggests a growing determination in Jakarta for Indonesia to impose its will on Papua, rather than resolve the issues of governance in the province. The proposal follows the appointment of InspectorGeneral Timbul Silaen, the head of police in East Timor in 1999, as the commander in Papua. Together with reports that one of the East Timorese militia leaders, Eurico Guterres, had established a pro-Indonesia militia in Papua, this raises the prospect that the Indonesian government is intending to implement in Papua in 2004 policies that provoked international intervention in East Timor in 1999. (The name of the western half of New Guinea has been a matter of political controversy since the 1940s. This article uses the names Papua, West Papua, Netherlands New Guinea, West Irian and Irian Jaya as appropriate to the context).

Papua and East Timor have different colonial pasts. The history of how they became part of Indonesia also diverges significantly. However, both territories have been the focus of differences between Indonesia and Australia that have coloured nearly all aspects of bilateral relations for protracted periods of time. Both Papua and East Timor touch on issues of great sensitivity for Indonesia and Australia. First and foremost among these are Indonesian sovereignty and national unity in regions on the Christian and Melanesian periphery of Indonesia's religious and ethnic mosaic. One of the legacies of the Pacific War was an Australian interest in the security, stability and governance of the eastern-most regions of the archipelago nearest to its own territory. In the post-Cold War era, governance has come to subsume issues such as human rights, indigenous rights and the right of self-determination.

This article will examine how Australia, in the course of the dispute of the sovereignty of West New Guinea, came to accept Indonesia on Indonesian terms - its territory, its multi-ethnic, multi-faith character and its underlying rationale as a nation state. In 1962, Australia accepted, however grudgingly, the incorporation of Papua into Indonesia. Australia came to appreciate the crucial strategic interest it had in developing close and cooperative relations with Indonesia. The second part of the article discusses the growth Papuan identity under Indonesian rule as well as the development of Indonesia's policies as the government faced the Papuan challenge to its sovereignty, following the resignation of President Soeharto. The third part of the article looks at Australia's policy options as Indonesia adopts strategies to repress the Papuan independence

Richard Chauvel is Director of the Australia Asia Pacific Institute at Victoria University, Melbourne. 
movement that rely increasingly on the use of force. If the dispute over West New Guinea was the means through which Australia came to terms with Indonesia, then devising the appropriate policy towards Indonesian governance in Papua shows how difficult it is to live with Indonesia.

\section{West New Guinea: 12 Long Years of Discord}

West New Guinea was the focus of the first major dispute between Australia and Indonesia. In 1950 the Menzies government asserted that Australia had a vital strategic interest in the future administration of West New Guinea. In the view of Percy Spender, the then Minister of External Affairs, the territory did not form part of Indonesia, but rather had more in common with the then Australian territories of New Guinea and Papua. Spender recognised that Australia also had a vital interest in the political and economic stability of Indonesia. The inclusion of West New Guinea in Indonesia would not add to regional stability, but rather form a weakness in Southeast Asian strategic planning. Australia wanted The Netherlands to retain its sovereignty in the territory and offered economic, administrative and defence assistance so that The Netherlands would not give in to Indonesia's demands.

Spender had established a policy that would see Australia in conflict with Indonesia over the status of a territory that Indonesia claimed as part of its national territory since the 1945 proclamation of independence. The West New Guinea dispute would colour nearly every aspect of Australia's relations with Indonesia for twelve years. In Indonesian eyes, the February 1950 Cabinet decision transformed Australia from being its closest western supporter during the struggle for independence to its most clearly identified opponent, along with the Dutch. Australia's strategic assessment of West New Guinea's importance was much influenced by the then still fresh memories of the campaign against Japanese forces in New Guinea. There was a strong desire to see that the territory did not come under the administration of an Asian power that would have a land border with Australian administered territories. The policy of supporting continued Dutch administration was not motivated by any especially warm feelings towards the Dutch nor out of any concern for what might be construed as Papuan interests. The objective was to keep Indonesia out.

As Indonesia became entangled in the Cold War during the mid and late 1950s, the tensions between the competing objectives of Australian policy became more acute. In 1958 Spender's successor, Richard Casey, saw the policy predicament with great clarity, but had no sense of a way out. How could Australia keep the Dutch in New Guinea, not make an enemy of Indonesia, and at the same time support the American objective of arming the Indonesian military to enable it to control the Communists?

In January 1959 the Menzies Cabinet recognised for the first time that the strategic importance of Indonesia to the US and Australia was greater than that of West New Guinea, and therefore it should be a major objective of Australian policy to keep Indonesia non-communist and friendly. Though recognising the 
greater significance of Indonesia, the Menzies government persisted in supporting continued Dutch sovereignty. It would be a further three years before the next External Affairs Minister, Garfield Barwick, recognised that the policy objectives Australia had pursued since 1950 were antithetical.

Following a 1957 Joint Statement with The Netherlands, Australia publicly supported the objective of self-determination for West New Guinea. The Statement foreshadowed the possibility that the Dutch and Australian halves of the island might form a greater Melanesian state upon independence. The Netherlands program for rapid political advancement and decolonization as an independent Papua by 1970, launched in 1960, had an actuality that unnerved Australian policy makers, particularly after the first stirrings of nationalist sentiment in West New Guinea. This came in the form of a Papuan assertion of the right to become an independent nation and the raising of the Papuan national flag on 1 December 1961, which provoked President Sukarno to issue his 'Trikora' commands.

The first of these was to destroy the Dutch-created puppet state of West Papua. In January 1962, Garfield Barwick saw the prospect that the Dutch might implement their program of decolonisation of West Papua as an undesirable outcome. He argued that ' ...the early emergence of an independent state of West New Guinea, unquestionably not economically viable, and certainly not militarily self defensible, so far from solving the problem, must be a standing provocation to Indonesian activity, probably of an aggressive military kind'. In the context of the Cold War, Barwick argued, the friendship of the Indonesian people would constitute a '...greater bulwark against the southward march of Communism...' than a Papuan state (Barwick 1962). Australia's commitment to selfdetermination in Papua, already undermined in 1959, vanished with the 1962 decision to support resolution of the dispute in Indonesia's favour.

Barwick understood that successful negotiations would probably include a 'face saving' formula for the protection of Papuan interests. The Papuans' right to choose their own future would be 'entirely dependent on Indonesian good faith', although there would be no way of ensuring that this aspect of the agreement would be carried out. The Australian government supported the later decision of Soeharto's New Order government to fulfil its international obligations under the 1962 New York Agreement by holding an act of self-determination in West Irian. The manner in which Indonesia conducted the 'Act of Free Choice' in 1969 caused the government embarrassment, but the outcome - confirming West Irian's status as a province of Indonesia - was the only one contemplated by Australia.

\section{Indonesian New Guinea}

Part of what Australia had come to accept about Indonesia in 1962 was the nationalists' assertion that West New Guinea had been an integral part of Indonesia since the proclamation of independence in 1945. Barwick had recognised that there was '...a real deep-seated and not illogical national 
sentiment for the attainment of sovereignty over the Territory...[among]...a substantial, responsible and wide-spread Indonesian opinion' (Barwick 1962). Contrary to the arguments that The Netherlands and Australia advanced during the dispute, West New Guinea's inclusion was important precisely because its inhabitants were ethnically different from many other Indonesians. It showed that Indonesia was born of a common political struggle, rather than a nation that rested on a shared ethnic and cultural heritage.

The nationalists' assertion that West Irian is an integral part of Indonesia is the golden thread that runs through successive Indonesian governments' policies, first against the Dutch challenge to its sovereignty and, since 1961, against the Papuan national challenge. In 1962 Australia made a strategic choice that its national interest lay in developing a friendly and cooperative relationship with a strong and united Indonesia. Barwick's concerns about the emergence of an unviable and defenceless independent Papua were reflected a decade later in the decisions of the Whitlam and Fraser governments with respect to East Timor.

The first sign of nationalist activities in Papua was one of the factors that prompted Sukarno to raise the stakes in the struggle with the Dutch by threatening military action. Sukarno understood that a rival Papuan national claim to West New Guinea posed a far greater threat to Indonesia's own claim than the continuation of Dutch colonial rule. Nevertheless, when Indonesia assumed administrative authority, officials found that the Papuan political leaders were less sophisticated, less established in their nationalist objectives and less well organised than the Indonesians had feared. In the first couple of months most of the Papuan leaders were persuaded, by one means or another, to cooperate with the Indonesian administration. Australian observers were not much impressed with the first generation of Papuan nationalists. The Australian Liaison Officer with the United Nations Temporary Executive Authority admired the skill with which his Indonesian colleagues worked with the Papuan leaders. He observed amity and full acceptance between the two groups: 'There is certainly no evidence of New Guinea “Nationalism””.

Even today it is not uncommon for influential Indonesians to blame the Dutch for Indonesia's problems in Papua. It is asserted that the Dutch deliberately cultivated false aspirations, including that of an independent Papuan state. Yet in 1962 the ideal of independent Papua was limited to the several thousands of Dutch educated Papuans scattered around the small urban centres of Netherlands New Guinea. They were officials, police, soldiers, paramedics, teachers and workers in the Sorong oil industry. The elite found the prospect of an independent Papua separate from Indonesia an attractive proposition. However, the idea of Papua, let alone an independent nation state of West Papua, had limited currency outside these circles.

The Papuan nationalists of the post Soeharto era have looked back to 1961 for inspiration and political symbols. They have adopted the Morning Star Flag and the other national symbols chosen then. The 1961 flag raising ceremony was reinterpreted as a declaration of independence. However, what the nationalists, organised in the Presidium Dewan Papua, achieved in 1999-2000 during the 
'Papuan Spring' - the establishment of a territory-wide organisation, and the mobilisation of widespread support for the straightforward demand for Papuan independence through peaceful dialogue - was far beyond anything that the leaders of the earlier generation could have imagined.

After the Presidium's Papuan Congress of mid 2000, an Indonesian intelligence report observed that the atmosphere down to the village level was one of euphoria and enthusiasm with the idea of Merdeka (independence). Those supporting Merdeka were increasingly cohesive and were endeavouring to 'socialise' the results of the Congress throughout Irian Jaya, elsewhere in Indonesia and internationally. Without wanting to diminish the achievements of the Papuan leaders, they were greatly assisted in the consolidation and dissemination of a Papuan identity by the policies and practices of the Sukarno and Soeharto governments. Ironically and sadly, the rhetoric of Indonesia's own nationalists seems an appropriate description of development of a pan-Papuan identity. Papuan identity flourished and spread, not out of a shared ethnic, religious or cultural heritage, but as a common struggle against Indonesian rule.

Indonesians rightly considered the negotiated settlement with the Dutch in the 1962 New York Agreement as a great nationalist victory. Indonesia had liberated the Irianese from the yoke of Dutch colonialism. In Papuan experience this transition might have seemed different - more like swapping a paternalistic, mostly benign and materially generous colonial regime with a repressive, corrupt and military dominated one that could not make up its mind whether its mission in West Irian was to civilise the indigenous inhabitants or treat them as fellow citizens.

The sporadic and localised Papuan resistance to Indonesian rule that came to be known under the umbrella label of the Organisasi Papua Merdeka (OPM, Organisation for Papuan Independence) challenged and embarrassed the military but, ultimately, has never threatened Indonesian control of the province. The legacy of the OPM is important in two respects. First, however ineffective it might have been as a military organisation, the OPM served to keep the ideal of Papuan independence alive. Few Papuans made the decision to go bush and join the OPM, but many more identified with the OPM. Second, and not unrelated, was the response that the OPM drew from the security forces. The 'security approach' that characterised the Soeharto government's response to armed resistance in Irian Jaya, as elsewhere in Indonesia, brought with it the seemingly inevitable widespread and frequent human rights abuses. The result was that the security approach itself became one of the factors fuelling anti-Indonesian sentiment. The massive influx of transmigrants was another aspect of Indonesian rule that gave Papuans a sense that they were being dispossessed of their own homeland. Indonesia has been able to maintain its authority in Papua, but has done so largely without the consent of the Papuan population. Not many Papuans have been convinced that their preferred political future should be as part of Indonesia. 


\section{Could Reformasi be Tolerated in Papua?}

Nearly three decades after Indonesians thought they had liberated the Papuans, they were confronted with a strong resurgence and transformation of the Papuan nationalist movement. The Papuan renaissance followed Soeharto's forced resignation in May 1998, and its success was a measure of the failure of Soeharto's policies. It coincided with the struggle of many Indonesians to create a more open, plural and competitive political system. President Habibie received a delegation of 100 Papuan leaders in February 1999, shortly after he had announced that the East Timorese would be given the choice of autonomy within Indonesia or independence. The Papuans' demand was straightforward. They demanded independence and wanted to achieve it through peaceful dialogue with the Indonesian government.

Habibie was taken aback by the demand for independence; he gave no formal response at the meeting. Indonesian governments were accustomed to separatist demands for independence, but less so to groups that expected to achieve their objectives through peaceful negotiations. The Papuan campaign was awkward because it coincided with Indonesia's own process of democratisation. Habibie and his successors have been confronted with the dilemma of how much freedom of expression and organization could be tolerated in Papua when those freedoms were used to advocate and successfully mobilize widespread support for Papua's independence.

Habibie's successor, Abdurrahman Wahid, Indonesia's first democratically elected President, sought to resolve the dilemma by attempting to accommodate Papuan aspirations within Indonesia. He changed the name of the province from Irian Jaya to Papua and permitted the Morning Star flag to be flown. However, Wahid made it clear that it was his duty as President to defend the territorial integrity of Indonesia. Following his visit to Papua to celebrate the New Year in 2000, Wahid maintained an intermittent dialogue with the Papuan leaders. He contributed to funding the Presidium's Papuan Congress. The Presidium considered that it had received a popular mandate from the Congress to advance the struggle for independence.

The Congress was also the turning point of Indonesian policy towards the Papuan independence movement. Wahid's accommodation of Papuan aspirations was the focus of criticism at the Annual Session of the People's Consultative Assembly (MPR) in August 2000. The president's agreement to change the province's name to Papua and his granting of permission to fly the Morning Star flag were rejected. He was given the task of taking decisive action against separatism and implementing special autonomy for Papua and Aceh.

The MPR session was indicative of the limits of the political elite's tolerance of Wahid's attempts to accommodate Papuan aspirations. Within the security and intelligence organisations, his policies had caused considerable disquiet. One Jayapura police report argued the president's financial contribution to the holding of the Congress provided the Presidium with a very broad opportunity to organize 
and use the president's support to its advantage. The president's permission to fly the Morning Star flag complicated the position of the security forces in the field. The separatist groups used the issues of democratisation and human rights to weaken the morale of government officials. The government gave the separatist groups the opportunity to 'socialize' the results of the Congress. A memorandum to the Minister of Internal Affairs argued that it was necessary to take immediate, concrete and appropriate actions to anticipate further expansion of the '... euphoria and enthusiasm for the idea of Merdeka (independence)...' that the Congress had stimulated. It envisaged graduated activities, both overt and clandestine, targeting a broad spectrum of Papuan leaders. It argued that the implementation of both regional autonomy and partition of the province should be accelerated.

Government approaches to the dilemma posed by the Papuan demands for independence was reflected in vacillations in policy from the repressive to the accommodative. The vacillations are also indicative of the significant differences in approach within both Wahid's and Megawati Soekarnoputri's governments. In the months after the 2000 Annual Session of the MPR both approaches were evidenced. The government's determination to remove the symbols of Papuan nationalism from public display, the arrest and trial of five leaders of the Presidium for treason, the murder of Theys Eluay - the Presidium's figurehead and one of the five on trial, by Kopassus (Special Forces) soldiers in November 2001 - and the indiscriminate reprisals in response to Papuan attacks on the security forces, were examples of the former.

With these measures the government reasserted its authority in Papua and closed down the political space in which the independence movement had flourished. However, the 'Papuan Spring' revealed something of the fragility of Indonesian authority and the lack of Papuan consent for Indonesian rule. The imposition of Jakarta's authority has come with a heavy reliance on force and state violence. The experience of the New Order would suggest that this might ultimately be counter-productive. Repression risks fueling the resentment it is supposed to quell.

Although the implementation of special autonomy was part of the MPR's instruction to Wahid to deal with the separatist challenge in Papua, the way in which the special autonomy law was formulated accommodated many Papuan interests and aspirations as these had been articulated at the Presidium's Papuan Congress. Wahid's acknowledgement of the name Papua and the Morning Star flag was much admired by Papuans, but perhaps his greatest gift to Papuan interests was the policy vacuum surrounding special autonomy. Special autonomy for Papua had been part of the Broad Outlines of Government Policy (GBHN), 1999-2004. The MPR had instructed Wahid to implement it, but his administration had done little to give substance to the policy. The policy vacuum was filled by the provincial government of Papua and the special autonomy team of academics, officials, NGO leaders and intellectuals appointed by the governor. The special autonomy law of September 2001 (Law 21/2001) was based on proposals submitted by the governor of Papua and negotiated between a special 
committee of the House of Representatives (DPR) and the governor's special autonomy team. The DPR's passing of the legislation did not imply its acceptance within the government.

The Law established Papua as a region of self-government within Indonesia. It provided for a substantial devolution of decision-making authority and distribution of financial resources from the centre to the province. With the establishment of an ethnic Papuan upper house (MRP), it sought to promote and protect Papuan interests. The province would be called Papua, and it would have its own flag, anthem and coat of arms, in addition to the Indonesian national ones.

\section{Megawati’s Old Order, 2001-04}

In her first Independence Day speech on 16 August 2001 President Megawati Soekarnoputri committed her government to special autonomy for Papua. However, it became evident that there were people within the government who had fundamental objections to key aspects of the law. They had not been involved in its formulation, but were in a position to undermine its implementation. For these people special autonomy was too great a concession. It gave strong expression to Papuan national aspirations and was an affront to many core Indonesian nationalist beliefs. If implemented, the law would empower and resource a Papuan elite in Jayapura—an elite whose loyalties were suspect.

Rather than a means to secure Papua within the national fold, special autonomy was thought of as a step towards Papuan independence. The governor of the National Resilience Institute (Lemhannas), Professor Dr Ermaya Suradinata, argued in January 2002 that the partition of Irian Jaya, was the best solution to the threat of national disintegration posed by special autonomy for the province of Papua. Among the objectives of partition was to isolate and marginalise the Papuan advocates of independence (disintegrasi) and undermine the symbolic nexus that the name Papua and the Morning Star flag had with Papuan nationalism. The three provinces would have different cultural identities. This line of thinking became government policy with Presidential Instruction 1/2003 to divide the province into three: West Irian Jaya, Central Irian Jaya and Irian Jaya. Reflecting Ermaya's reasoning, the three provinces would assume the government's preferred nomenclature 'Irian Jaya'.

What followed during 2003 was confusion and an apparent impasse in policy as the government struggled to explain how division of the province could be compatible with special autonomy, which officially the government still espoused, although it had not issued the necessary regulations to enable effective implementation. The provincial authorities in Papua had not been consulted about the division of the province, which seemed to run counter to both the spirit and the letter of the special autonomy law. Given the participation of the provincial government and much of the academic and intellectual elite in the formulation of the law, the lack of consultation was deeply resented in the province capital, Jayapura. The response from the established Papuan elite in Jayapura and Jakarta 
has been strong and quite uniform in its rejection of partition. For these people partition was an attack on special autonomy. Looked at from a longer historical perspective, the decision to divide the province seemed to have lost Jakarta the support of the one group of Papuans who, out of an assessment of their own interests, have supported an Indonesian policy relating to the governance of Papua.

Yet it was this group that Lemhannas and others within the government considered part of the problem. Their loyalty to the State was suspect, yet special autonomy empowered them with decision-making authority and resources. Outside the established elite and those out of power in Jayapura, the government found some Papuan supporters for partition. The social and political tensions in Papua generated by the government's decision to partition the province were most evident at the attempted inauguration of the province of Central Irian Jaya on 23 August 2003. The inauguration in Timika sparked several days of violence between pro- and anti-partition groups of Papuans and pro-partition immigrants, which resulted in the death of five people and injuries to dozens of others.

The government's initial responses to the violence were confused and confusing. Security Minister Susilo Bambang Yudhoyono papered over some of the cracks in the government's position when he announced that partition would be put on hold and the status quo would be maintained - meaning that the province of West Irian Jaya would remain, but Central Irian Jaya would not be established. Together with the DPR, the government would review the laws relating to Papua. At least in the Security Minister's statement, if not in those of his President and Ministerial colleagues, there was some recognition of the contradictions between special autonomy and division of the province. The political tensions and violence generated by the government's determination to divide Papua and undermine special autonomy, as well as the confusion within government policy, suggests that there is no easy return to the old ways of Indonesian governance in Papua.

If it is the case that special autonomy has been abandoned or significantly undermined, this raises the question of why it has been so difficult for governments to accommodate Papuan aspirations within the Indonesian state. This article has stressed the nationalist ideological obstacles to meaningful accommodation as well as the anxieties that special autonomy would empower a distrusted Papuan elite. To loosen controls risks opening up the political space for Papuan nationalist activities. Besides these factors, the political economy of the security forces in Irian Jaya and the symbiotic relationships the security forces have developed with resource companies - most notably the copper and gold mining giant, Freeport - have created an institutional imperative for the maintenance of the territory as a zone of conflict. The security forces have no interest in conflict getting out of control, but they have little interest in its resolution. Whether the core of the government's difficulties related to issues of nationalist ideology, the control of decision making and resources, or the institutional imperatives of the security forces, these factors are deep-rooted, systemic and not open to easy modification. 
The shift in government policy in Papua from an inclusive framework capable of resolving the issues of governance in Papua to re-imposing Jakarta's control through partition occurred in the context of a determination to defend Indonesia's unity and territorial integrity. This context is the breakdown of negotiations about Aceh and the subsequent military campaign against the armed independence movement. One of the consistent themes in Susilo Bambang Yudhoyono's speeches in mid 2003 has been that Indonesia's unity and territorial integrity is non-negotiable. Indonesia's national security priority is fighting armed separatism rather than terrorism. He recognised that the most serious military threat was in Aceh, whereas the challenge in Papua was political.

\section{Australia's Interests and Options}

Related to the preoccupation with unity and territorial integrity have been concerns about international-not least, Australian-interference in Irian Jaya. For example, at the time of the killing of one Indonesian and two American teachers near the Freeport mine on August 30 2002, Susilo Bambang Yudhoyono ordered the National Intelligence Agency to investigate a conference at Sydney University's Centre for Peace and Conflict Resolution. Eight Papuans attended the conference; Susilo Bambang Yudhoyono said the Papuan group left for Australia within hours of the killings at Freeport. The objective of the investigation was to 'prevent any assumption that Australia is involved in this case' (Garnaut, 2002).

When Australian Prime Minister, John Howard, visited Jakarta in February 2003, President Megawati and her ministers raised the issue of the support of some groups in Australia for Papuan independence and whether the Australian government funded aid organizations that supported independence. Marty Natalegawa, a spokesman for the Department of Foreign Affairs, told the press:

We know the Australian government's view in support of our territorial integrity. At the same time we will make known our concern not to allow certain groups under the guise of democracy, free speech and the like basically to try to disrupt and disturb our national unity, which we will defend, as would any other sovereign country. (Skehan, 2003).

The precedent established by international intervention in East Timor in 1999 is both the source of Indonesian anxieties and the reason for lack of credibility in Australian reassurances. Shortly after the loss of East Timor, former Foreign Minister, Ali Alatas, argued that the doctrine of 'humanitarian intervention' enables both external forces to exploit internal conflicts to their own political ends and elements within Indonesia to create crises to seek international attention and provoke interference. Presumably the fear is that excessive military action in Papua will enable NGOs and solidarity groups to mobilize domestic pressure on their governments to reconsider their recognition of Indonesian sovereignty in 
Papua. Indonesia's international position in relation to Papua has been difficult since the Presidential Instruction: special autonomy had been sold to friendly governments as the policy framework in which the Papua problem could be resolved within the framework of the Indonesian state. Friendly governments, including Australia, supported special autonomy, not least because it absolved them from having to make difficult decisions about Indonesian sovereignty.

Since the Presidential Instruction was issued, foreign support for special autonomy has been regarded with suspicion. From Jakarta's perspective, the protracted difficulties between Indonesia and the US about an appropriate investigation into responsibility for the killing of the three teachers near the Freeport mine have thrown an unwelcome spotlight onto governance in Papua. It is in this international context that the appointment of Timbul Silaen as the Police commander, together with reports of Eurico Guterres' militia activities, are important. They do not imply any significant change in policy, but are unhappy reminders in the eyes of the international community of what went wrong for Indonesia in East Timor in 1999.

The Timor precedent creates policy difficulties with respect to Papua for the Australian government. As Professor Andrew McIntyre has noted, Papua is a lose-lose proposition for Australian policy makers. In response to the Indonesian government's concerns about AusAID funding for NGOs that support Papuan independence, the Australian government has been fulsome with its frequent statements of support for Indonesia's sovereignty in Irian Jaya. However, as implied by Natalegawa's statement, cited above, the credibility of these statements in the eyes of the government in Jakarta are in inverse proportion to their frequency. The Timor precedent evokes the response that, while support for Indonesian sovereignty had been Australia's long-standing position, this support evaporated when it mattered most to Jakarta. Contrary to Australia's objectives in 1999 (as expressed in a letter from Howard to Habibie in December 1998 concerning the future of East Timor), the Howard government's later celebration of its successful role in East Timor has convinced many Indonesians that East Timorese independence was the desired outcome for Australia. This impression fuels suspicions about Australia's intentions in Papua.

In these circumstances, what are Australia's interests and how can they best be advanced? Garfield Barwick’s 1962 assessment that Australia's interest lay in close and cooperative relations with a strong and united Indonesia remains Australia's preferred strategic objective, intervention in East Timor notwithstanding - indeed, perhaps reinforced by the subsequent experience in Timor. Does Australia need another, not so small, Melanesian state to support? The fragmentation of Indonesia, a less likely prospect than it seemed immediately after the fall of Soeharto, would greatly complicate Australia's strategic environment. Even the separation of Aceh and Papua, particularly the latter, would have this effect. However, the short and long-term trends in Indonesian governance in Irian Jaya, if they were to continue, might make international support for Indonesian rule in Papua more difficult to sustain. 
Australia was not able to sustain its preferred strategic objective with respect to East Timor. The decision to intervene broke a psycho-strategic taboo. Indonesia's fragmentation was no longer unthinkable, nor was Australian intervention. With respect to Papua's neighbours, Australia has intervened to restore law and order in the Solomon islands, and provided a highly interventionist support program in PNG. In the context of Australia's support program in Papua New Guinea, Foreign Minister Alexander Downer stated that (Forbes, 2003):

We are not willing to stand back and watch regional neighbours descend into instability. Countries like PNG still lack the preventative and enforcement capabilities that they need to combat corruption.

On occasions Downer has expanded the rhetoric in more abstract terms: 'Sovereignty, in our view is not absolute. Acting for the benefit of humanity is more important.' (Burchill, 2003) Indonesia is not PNG or the Solomons. Australia has sufficient authority and influence in PNG and the Solomons for its intervention to be at the invitation of the respective governments. This is most unlikely to happen in Indonesia.

Australia's reengagement in PNG not only is an example of Australia's willingness to intervene in a neighbour's domestic affairs, but also heightens Australian interest in developments across the border in Papua. Political instability in Papua and refugee flows into PNG would complicate Australia's rehabilitation efforts in PNG, and Papuan use of sanctuary in PNG would be resented in Jakarta.

The lingering and deeply felt Indonesian resentment about Australia's role in the loss of East Timor, together with the history of the earlier dispute concerning West New Guinea, suggests that any real or imagined Australian involvement in Papua would have a profound and enduring impact on Australia's relations with the government of Indonesia. Papua is of much greater economic value to Indonesia than East Timor was and is an integral part of the Indonesian nationalist enterprise. An understanding of Indonesian sensitivities is the basis for much academic advice on Papua that Australia has little choice but to continue its formal support for Indonesian sovereignty. As Professor Jamie Mackie (2003) warned, if Australia were to say anything else, it would arouse a hornet's nest in Indonesia.

Such are Indonesian sensitivities created by the East Timor intervention that Sidney Jones, Indonesia Director of the International Crisis Group, advised that it would be most unwise for Australia to offer to mediate in Papua at the time of the Timika violence sparked by the attempted establishment of the new province of Central Irian Jaya (Jones 2003). Neither Mackie nor Jones is exaggerating Indonesian sensitivities. However, frequent Australian ritual protestations of support for Indonesia's sovereignty do little to convince the Indonesian government that Australia shares some of its strategic interests in Papua. A policy that amounts to little more than cross the fingers, hope for the best and look the other way makes no contribution to resolving the governance problem that poses a threat to Australia's strategic interests. The implied assumption underlying the 
policy is that while the situation in Papua might be bad, it has been so for most of the period of Indonesian rule and will not become much worse. The discussion of Indonesian policy developments in this article suggests that such an assumption is optimistic. The difficult judgement for Australian policy makers is how much worse would the situation have to become in Papua before the Australian position became untenable.

Australian diplomatic endeavours to assist the government in Jakarta to resolve some of its governance problems in Papua will evoke suspicion and resentment. However, the magnitude of Jakarta's displeasure at such endeavours will be minor compared with that which any more active Australian intervention would provoke, if the situation in Papua were to disintegrate further and continued Indonesian rule to become untenable.

This article has argued that the long-term pattern of political change in Papua and the short-term trend in policy are likely to make Jakarta's position in Papua increasingly difficult. Papuan identity is much more widespread, and the commitment to a Papuan nation much stronger, in 2004 than when the Dutch left. The educated elite in Papua is much more numerous, skilled and politically experienced than in 1962. The obstacles to more inclusive and accommodative Indonesian policies in Papua are deeply rooted and systemic. The government's current attempts to suppress the independence movement seem likely to generate political instability and social tensions, as well as further to consolidate Papuan support for independence. The challenge for Australian policy makers is to persuade their Indonesian counterparts that they share some strategic interests in Papua, and that these are best served by the establishment of a form of governance that accommodates Papuan interests and aspirations.

Many Papuans believe that their interests were sacrificed in the New York Agreement and by the UN's acceptance of the results of the 1969 Act of Free Choice. There has been little in Papuan experience since 1962 to convince them that their preferred political future should be as part of Indonesia. It is difficult to imagine that anything less than near total transformation of Indonesian governance will begin to persuade them otherwise.

\section{References}

Barwick, G. (1962), Memorandum by Minister for External Affairs on Cabinet Submission No. 10, 11 January, Prime Minister's file C508 pt 3, CRS A4940, Australian National Archives.

Burchill, S. (2003), 'What the West Wants from Indonesia’, Joyo Indonesia News, Z-Net, October.

Forbes, M. (2003), 'Troops for PNG Mission Ruled Out’, The Age, 15 October.

Garnaut, J. (2002), 'Outrage as Murders Linked to University’, Sydney Morning Herald, 13 September. 
Jones, S. (2003), 'Papua Province: Indonesia's Next Flashpoint?’, Interview on Asia Pacific/Radio Australia, 5 October.

Mackie, J. (2003), 'Relations with Australia Affected by Papua', Interview on Asia Pacific/Radio Australia, 9 May.

Skehan, C. (2003), 'A Papuan Free for All', Sydney Morning Herald, 11 March, http://www.smh.com.au/articles/2003/03/10/1047144926255.html.

The author is indebted for comments from two anonymous referees. 